\title{
Ethylene Polymerization Catalyzed by Neutral Nickel(II) Complex with O`N-Chelating Ligand
}

\author{
Mitsufumi Nodono, ${ }^{\dagger}$ Bruce M. NovaK, ${ }^{*}$ and Paul T. Boyle* \\ Corporate Research Laboratories, Mitsubishi Rayon Co., Ltd., 20-1 Miyuki-cho, Otake, 739-0693, Japan \\ *Department of Chemistry, North Carolina State University, Raleigh, NC 27695, U.S.A.
}

(Received September 16, 2003; Accepted November 17, 2003)

\begin{abstract}
We have achieved the synthesis of neutral nickel catalyst with the modified $\mathrm{O}^{\wedge} \mathrm{N}$-chelating ligand for the ethylene polymerization. The activity of the catalyst, and the molecular weight and the branching structure of the polymer obtained strongly depend on the ligand structure as well as the presence of $\mathrm{Ni}(\mathrm{COD})_{2}$ which is used as an activator. The crystal structure of the catalyst was determined and the long nickel-phosphine bond length seems to play an important role for increasing the polymerization activity.

KEY WORDS Neutral Nickel Complex / Ethylene Polymerization / Oligomerization / Polyethylene /
\end{abstract}

Neutral Ni complexes have been intensively investigated as the catalysts for highly active oligomerization/polymerization of ethylene. ${ }^{1}$ While the SHOPtype catalysts based on $\mathrm{P}^{\prime} \mathrm{O}$-chelated complexes can produce higher $\alpha$-olefins as a result of the favorable $\beta$-H elimination for those late transition metal alkyl species, several groups recently reported a new class of neutral $\mathrm{Ni}(\mathrm{II})$ catalysts with salicylaldiminato ligands which are able to produce high molecular weight polyolefins. ${ }^{2}$ These neutral $\mathrm{Ni}(\mathrm{II})$ catalysts are less oxophilic compared to early transition metal or cationic late transition metal catalysts and do not require co-catalysts necessarily to show polymerization activity. They are also attracting strong interests for several unique polymerization systems, for example, single component catalysts ${ }^{2,3}$ or olefin polymerizations in water media. ${ }^{4}$

\section{EXPERIMENTAL}

All manipulations involving organonickel compounds were done under either nitrogen or argon with use of standard Schlenk techniques. All solvents were thoroughly dried over $\mathrm{Na} / \mathrm{K}$ alloy or passed through Alumina/CuO columns and degassed prior to use.

Nuclear magnetic resonance (NMR) spectra were recorded on a General Electronics GE-300 instrument. The ${ }^{1} \mathrm{H}$ and ${ }^{13} \mathrm{C} N M R$ spectra for ligands and nickel complexes were recorded in chloroform- $d_{1}$ or benzene- $d_{6}$, and chemical shifts were determined with the use of the residual proton absorption of chloroform at $\delta 7.26(\mathrm{H})$ and $77.23(\mathrm{C})$ and benzene at $\delta$ $7.15(\mathrm{H})$ and $128.39(\mathrm{C})$. The following abbreviations are used for the observed peak multiplicities: $\mathrm{s}=$ singlet, $\mathrm{d}=$ doublet, $\mathrm{dd}=$ doublet of doublets, $\mathrm{t}=$ trip- let, $\mathrm{q}=$ quartet, $\mathrm{sep}=$ septet, $\mathrm{m}=$ multiplet. Elemental analyses were performed by Atlantic Microlab. Inc. of Norcross, GA.

\section{Synthesis of Ligand for 1}

The starting materials, 7-bromoindole ${ }^{5}$ and 7formylindole, ${ }^{6}$ were prepared according to literature procedures. A $0.5 \mathrm{ml}$ of formic acid was added into a solution of 7-formylindole $(4.5 \mathrm{~g}, 31.0 \mathrm{mmol})$ and 2,6-diisopropylaniline $(5.5 \mathrm{~g}, 31.0 \mathrm{mmol})$ in ethanol $(50 \mathrm{~mL})$. The reaction mixture was stirred overnight at room temperature, and then concentration afforded $\mathbf{1}$ as a yellow crystalline solid (9.04 g, 96\%). ${ }^{1} \mathrm{H}$ NMR $\left(300 \mathrm{MHz}, \mathrm{CDCl}_{3}, 25^{\circ} \mathrm{C}\right): \delta 10.76(\mathrm{br}, 1 \mathrm{H}, \mathrm{NH}), 8.41$ $(\mathrm{s}, 1 \mathrm{H},-\mathrm{C} H=\mathrm{N}-), 7.81(\mathrm{~d}, J=8.1 \mathrm{~Hz}, 1 \mathrm{H}, \mathrm{Ar}-H)$, 7.37 (d, $J=7.3 \mathrm{~Hz}, 1 \mathrm{H}, \mathrm{Ar}-H), 7.28$ (t, $1 \mathrm{H}, \mathrm{Ar}-H)$, 7.10-7.25 (m, 4H, Ar-H), $6.63(\mathrm{t}, 1 \mathrm{H}, \mathrm{Ar}-H), 3.06$ (sep, $\left.2 \mathrm{H},-\mathrm{CH}\left(\mathrm{CH}_{3}\right)_{2}\right), 1.17(\mathrm{~d}, J=8.8 \mathrm{~Hz}, 12 \mathrm{H}$, $\left.-\mathrm{CH}\left(\mathrm{CH}_{3}\right)_{2}\right) ;{ }^{13} \mathrm{CNMR}\left(75 \mathrm{MHz}, \mathrm{CDCl}_{3}, 25^{\circ} \mathrm{C}\right): \delta$ $164.1,149.4,138.1,134.2,128.8,126.8,125.6$, 124.8, 123.4, 119.4, 102.6, 28.2, 23.9. Anal. calcd. for $\mathrm{C}_{21} \mathrm{H}_{24} \mathrm{~N}_{2}$ : C, 82.85; H, 7.95; N, 9.20. Found: C, $82.83 ; \mathrm{H}, 8.07$; N, 9.19.

\section{Synthesis of $\mathbf{1}$}

A solution of the ligand $(0.8 \mathrm{~g}, 2.63 \mathrm{mmol})$ in THF $(10 \mathrm{ml})$ was added dropwisely into a suspension of $\mathrm{KH}$ $(0.2 \mathrm{~g} .5 .0 \mathrm{mmol})$ in $\mathrm{THF}(10 \mathrm{~mL})$ at $0{ }^{\circ} \mathrm{C}$, and then the reaction mixture was stirred for $6 \mathrm{~h}$. The resulting suspension was filtrated and the filtrates were washed with THF $(5 \mathrm{~mL} \times 2)$. A solid of TlOAc $(1.31 \mathrm{~g}$, $5.0 \mathrm{mmol}$ ) was added into the combined THF solution at room temperature with stirring vigorously, and the reaction mixture was stirred for $1 \mathrm{~d}$ at room temperature. Then the resulting suspension was filtered and

${ }^{\dagger}$ To whom correspondence should be addressed (Fax: +81-827-53-8515, Tel: +81-827-53-8507, E-mail: nodono_mi@mrc.co.jp). 
the THF-soluble part was used for the reaction with trans- $\left(\mathrm{PPh}_{3}\right)_{2} \mathrm{Ni}(\mathrm{Ph}) \mathrm{Cl}$. To a toluene suspension of trans- $\left(\mathrm{PPh}_{3}\right)_{2} \mathrm{Ni}(\mathrm{Ph}) \mathrm{Cl}^{5}(1.83 \mathrm{~g}, 2.63 \mathrm{mmol})$, the THF solution obtained was added at room temperature. The color of the reaction mixture turned to deep red immediately. After stirring it overnight, the solvent was removed in vacuo and the residue was extracted with $\mathrm{CH}_{2} \mathrm{Cl}_{2}(10 \mathrm{~mL} \times 2)$. The $\mathrm{CH}_{2} \mathrm{Cl}_{2}$ solution was concentrated to $c a .10 \mathrm{~mL}$, and then pentane $(20 \mathrm{~mL})$ was added slowly. After standing it at room temperature for several days, the organonickel complex 1 was obtained as brown needles (42\%). ${ }^{1} \mathrm{H} N M R$ $\left(300 \mathrm{MHz}, \mathrm{C}_{6} \mathrm{D}_{6}, 25^{\circ} \mathrm{C}\right): \delta 8.35(\mathrm{~d}, J=8.0 \mathrm{~Hz}, 1 \mathrm{H}$, $-\mathrm{CH}=\mathrm{N}-), 7.94(\mathrm{~d}, J=1.5 \mathrm{~Hz}, 1 \mathrm{H}, \operatorname{Ar}-H), 7.70(\mathrm{t}$, $\left.6 \mathrm{H}, \mathrm{P}(\mathrm{Ar}-\mathrm{H})_{3}\right), 7.20(\mathrm{~d}, 1 \mathrm{H}, \operatorname{Ar}-H), 7.00-7.10(\mathrm{~m}$, $2 \mathrm{H}, \operatorname{Ar}-H), 6.8-7.0\left(\mathrm{~m}, 9 \mathrm{H}, \mathrm{P}(\mathrm{Ar}-H)_{3}\right), 6.67(\mathrm{~d}, J=$ $7.3 \mathrm{~Hz}, 2 \mathrm{H}, \mathrm{Ar}-H), 6.50(\mathrm{~d}, J=2.9 \mathrm{~Hz}, 1 \mathrm{H}, \mathrm{Ar}-H)$, $6.30(\mathrm{~d}, 1 \mathrm{H}, \mathrm{Ar}-H), 6.14$ (d, 2H, Ar-H), 4.29 (sep, $\left.2 \mathrm{H},-\mathrm{CH}\left(\mathrm{CH}_{3}\right)_{2}\right), 1.11(\mathrm{dd}, J=7.3 \mathrm{~Hz}, 6.6 \mathrm{~Hz}, 12 \mathrm{H}$, $\left.-\mathrm{CH}\left(\mathrm{CH}_{3}\right)_{2}\right) ;{ }^{13} \mathrm{CNMR}\left(75 \mathrm{MHz}, \mathrm{C}_{6} \mathrm{D}_{6}, 25^{\circ} \mathrm{C}\right): \delta$ $167.5,152.0,147.0,146.3,144.6,144.5,141.4$, $140.37,138.0,135.6,135.5,133.9,133.3,133.0$, $130.5,129.4,128.3,127.8,127.5,127.0,126.6$, $125.3,123.5,121.7,118.0,117.5,103.1,29.6,26.2$, 23.4. Anal. calcd. for $\mathrm{C}_{45} \mathrm{H}_{43} \mathrm{~N}_{2} \mathrm{PNi}$ : C, 77.05; H, 6.18; N, 3.99. Found: C, 76.99; H, 6.26; N, 3.91.

\section{Synthesis of Ligand for 2}

The starting material, $\left[\left\{\mathrm{Li}\left(\mathrm{Et}_{2} \mathrm{O}\right)\left(2,4,6-\left(\mathrm{CHMe}_{2}\right)_{3}-\right.\right.\right.$ $\left.\left.\mathrm{C}_{6} \mathrm{H}_{2}\right)\right\}_{2}$ ], was synthesized according to a literature procedure. ${ }^{7}$ A solution of $\left[\left\{\mathrm{Li}\left(\mathrm{Et}_{2} \mathrm{O}\right)(2,4,6-\right.\right.$ $\left.\left.\left.\left(\mathrm{CHMe}_{2}\right)_{3} \mathrm{C}_{6} \mathrm{H}_{2}\right)\right\}_{2}\right](35.3 \mathrm{mmol})$ in THF $(80 \mathrm{~mL})$ was added into a stirred solution of $\mathrm{ZnCl}_{2}(6.0 \mathrm{~g}, 45 \mathrm{mmol})$ in THF $(40 \mathrm{~mL})$ under nitrogen at $0{ }^{\circ} \mathrm{C}$. The resulting organozinc reagent was allowed to warm to room temperature and used immediately for the next reaction. The reaction of the organozinc reagent with anthranil was carried out according to a literature procedure. ${ }^{8}$ The reaction solution was stirred for $3 \mathrm{~d}$ at room temperature and then quenched by the addition of $1 \mathrm{~N} \mathrm{HCl}$ $(10 \mathrm{~mL})$. The reaction mixture was then poured into water $(150 \mathrm{~mL})$ and extracted with ether $(100 \mathrm{~mL} \times$ 2 ). The ether extracts were combined, washed, and concentrated to give crude product as yellow oil. The crude product was chromatographed over silica gel (pet. ether $\sim 90 \%$ pet. ether $/ 10 \%$ ether) to give the target product as yellow crystals in $32 \%$ yield. ${ }^{1} \mathrm{HNMR}\left(300 \mathrm{MHz}, \mathrm{CDCl}_{3}, 25^{\circ} \mathrm{C}\right): \delta 9.95(\mathrm{~s}, 1 \mathrm{H}$, $-\mathrm{CH}=\mathrm{O}), 9.51(\mathrm{~s}, 1 \mathrm{H}, \mathrm{NH}), 7.53(\mathrm{~d}, J=7.3 \mathrm{~Hz}, 1 \mathrm{H}$, Ar-H), 7.22 (t, $1 \mathrm{H}, \mathrm{Ar}-H$ ), 7.08 (s, 2H, Ar-H), 6.70 (t, $1 \mathrm{H}, \operatorname{Ar}-H), 6.25(\mathrm{~d}, J=8.1 \mathrm{~Hz}, 1 \mathrm{H}, \operatorname{Ar}-H), 3.04$ (sep, 2H, $\left.-\mathrm{CH}\left(\mathrm{CH}_{3}\right)_{2}\right), 2.94$ (sep, 1H, $\left.-\mathrm{CH}\left(\mathrm{CH}_{3}\right)_{2}\right)$, $1.29\left(\mathrm{~d}, J=7.3 \mathrm{~Hz}, 6 \mathrm{H},-\mathrm{CH}\left(\mathrm{CH}_{3}\right)_{2}\right), 1.15(\mathrm{~d}, J=$ $\left.7.3 \mathrm{~Hz}, 6 \mathrm{H},-\mathrm{CH}\left(\mathrm{CH}_{3}\right)_{2}\right), 1.10(\mathrm{~d}, J=7.3 \mathrm{~Hz}, 6 \mathrm{H}$, $\left.-\mathrm{CH}\left(\mathrm{CH}_{3}\right)_{2}\right) ;{ }^{13} \mathrm{CNMR}\left(75 \mathrm{MHz}, \mathrm{CDCl}_{3}, 25^{\circ} \mathrm{C}\right): \delta$
$194.5, \quad 151.6,148.5,147.1,136.4,135.6,131.2$, $122.1,118.2,115.8,113.0,34.5,28.7,24.8,24.3$, 23.4. Anal. calcd. for $\mathrm{C}_{22} \mathrm{H}_{29} \mathrm{NO}$ : C, 81.69; H, 9.04; $\mathrm{N}, 4.33$. Found: C, 81.81; H, 9.08; N, 4.16.

\section{Synthesis of $\mathbf{2}$}

The target organonickel complex $\mathbf{2}$ was obtained by the similar procedure for $\mathbf{1}$ except for using trans$\left(\mathrm{PPh}_{3}\right)_{2} \mathrm{Ni}(o$-tol $) \mathrm{Cl}$ instead of trans- $\left(\mathrm{PPh}_{3}\right)_{2} \mathrm{Ni}(\mathrm{Ph}) \mathrm{Cl}$. trans- $\left(\mathrm{PPh}_{3}\right)_{2} \mathrm{Ni}(o$-tol $) \mathrm{Cl}$ was prepared in similar manner as literature procedure. ${ }^{9}$ Recrystallization from $\mathrm{CH}_{2} \mathrm{Cl}_{2}$ /pentane afforded 2 as red crystals $(68 \%)$. ${ }^{1} \mathrm{HNMR}\left(300 \mathrm{MHz}, \mathrm{C}_{6} \mathrm{D}_{6}, 25^{\circ} \mathrm{C}\right): \delta 8.29(\mathrm{~s}, 1 \mathrm{H}$, $-\mathrm{CH}=\mathrm{O}), 7.56\left(\mathrm{t}, 6 \mathrm{H}, \mathrm{P}(\mathrm{Ar}-\mathrm{H})_{3}\right), 7.21(\mathrm{br}, 1 \mathrm{H}, \mathrm{Ar}-$ $H), 6.85-7.05\left(\mathrm{~m}, 9 \mathrm{H}, \mathrm{P}(\mathrm{Ar}-H)_{3}\right), 6.77(\mathrm{~d}, 1 \mathrm{H}, \mathrm{Ar}-$ $H$ ), 6.70 (s, $1 \mathrm{H}, \operatorname{Ar}-H), 6.4-6.6$ (m, 2H, Ar-H), 6.37 $(\mathrm{t}, 1 \mathrm{H}, \operatorname{Ar}-H), 6.27(\mathrm{~d}, 1 \mathrm{H}, \operatorname{Ar}-H), 6.21(\mathrm{~d}, 1 \mathrm{H}, \mathrm{Ar}-$ $H$ ), 6.05 (q, 2H, $\mathrm{Ar}-H), 4.69$ (sep, $\left.1 \mathrm{H},-\mathrm{CH}\left(\mathrm{CH}_{3}\right)_{2}\right)$, 3.24 (s, 3H, lut- $\left.\mathrm{CH}_{3}\right), 3.14$ (sep, $\left.1 \mathrm{H},-\mathrm{CH}\left(\mathrm{CH}_{3}\right)_{2}\right)$, $2.80\left(\mathrm{sep}, 1 \mathrm{H},-\mathrm{CH}\left(\mathrm{CH}_{3}\right)_{2}\right), 1.83(\mathrm{~d}, J=6.6 \mathrm{~Hz}, 3 \mathrm{H}$, $\left.-\mathrm{CH}\left(\mathrm{CH}_{3}\right)_{2}\right), 1.31\left(\mathrm{~d}, \mathrm{~J}=7.4 \mathrm{~Hz}, 3 \mathrm{H},-\mathrm{CH}\left(\mathrm{CH}_{3}\right)_{2}\right)$, $1.26\left(\mathrm{dd}, J=1.5 \mathrm{~Hz}, 6.6 \mathrm{~Hz}, 6 \mathrm{H},-\mathrm{CH}\left(\mathrm{CH}_{3}\right)_{2}\right), 1.10$ $\left(\mathrm{d}, \quad J=6.6 \mathrm{~Hz}, 3 \mathrm{H},-\mathrm{CH}\left(\mathrm{CH}_{3}\right)_{2}\right), 0.84 \quad(\mathrm{~d}, \quad J=$ $\left.6.6 \mathrm{~Hz}, 3 \mathrm{H},-\mathrm{CH}\left(\mathrm{CH}_{3}\right)_{2}\right) ;{ }^{13} \mathrm{CNMR}\left(75 \mathrm{MHz}, \mathrm{C}_{6} \mathrm{D}_{6}\right.$, $\left.25^{\circ} \mathrm{C}\right): \delta 180.3,157.4,145.26,143.1,142.7,139.1$, $136.1,135.0,134.9,133.6,132.6,132.2,130.1$, $128.3,127.5,123.6,123.3,122.0,121.7,121.5$, $118.4,113.5,35.1,29.6,28.4,26.8,26.7,26.6,25.4$, 25.2, 25.0, 23.9. Anal. calcd. for $\mathrm{C}_{47} \mathrm{H}_{50} \mathrm{NOPNi}$ : , 76.85; H, 6.86; N, 1.91. Found: C, 76.08; H, 6.77; N, 1.90 .

\section{General Procedure of Ethylene Polymerization}

To a $300 \mathrm{~mL}$ of Parr autoclave with a mechanical stirring bar, a $94 \mathrm{~mL}$ of toluene was added and degassed with ethylene $(3 \times 150 \mathrm{psi})$. The catalyst and the prescribed amount of $\mathrm{Ni}(\mathrm{COD})_{2}$ were dissolved into $4 \mathrm{~mL}$ of toluene respectively, and the catalyst solution was transferred into the autoclave by syringe after $5 \mathrm{~min}$. After the prescribed polymerization time under the prescribed ethylene pressure, ethylene pressure was then vented and reaction worked up to afford waxy or solid polyethylene. The branched structure and chain end structure were determined by ${ }^{1} \mathrm{H}$ and ${ }^{13} \mathrm{CNMR}$ by the use of 1,2,4-trichlorobenzene/benzene- $d_{6}$ as a solvent at $120^{\circ} \mathrm{C}$.

\section{Structure Solution and Refinement}

The structure was solved using SIR $92^{10}$ and refined using SHELXL-97. ${ }^{11}$ The space group $P 2{ }_{1} 2_{1} 2_{1}$ was determined based on systematic absences and intensity statistics. A direct-methods solution was calculated which provided most non-hydrogen atoms from the Emap. Full-matrix least squares/difference Fourier cycles were performed which located the remaining 


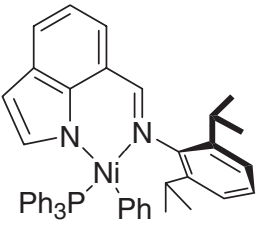

1

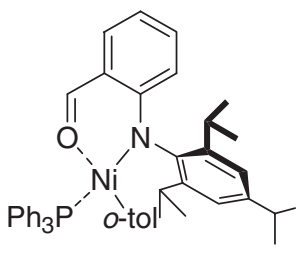

2

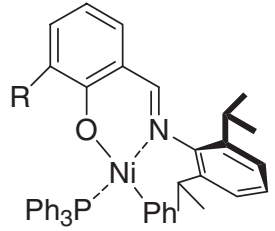

3(R=H), 4(R=Anthranyl)

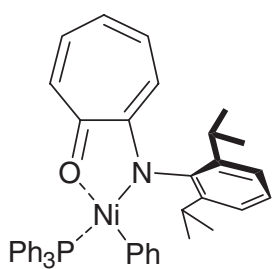

5

Figure 1. Neutral nickel complexes with $\mathrm{N}^{\wedge} \mathrm{N}$ - and $\mathrm{N}^{\wedge} \mathrm{O}$-chelating ligands.

Table I. Selected bond lengths $(\AA)$ and angles $\left({ }^{\circ}\right)$

\begin{tabular}{clllll}
\hline Ni complexes & \multicolumn{1}{c}{$\mathrm{Ni}-\mathrm{P}$} & $\mathrm{Ni}-\mathrm{C}$ & $\mathrm{Ni}-\mathrm{O}$ & $\mathrm{Ni}-\mathrm{N}$ & $\mathrm{X}-\mathrm{Ni}-\mathrm{Y}^{\mathrm{a}}$ \\
\hline $\mathbf{1}$ & $2.157(1)$ & $1.922(3)$ & $1.946(2)^{\mathrm{b}}$ & $1.960(2)^{\mathrm{c}}$ & 93.66 \\
$\mathbf{2}$ & $2.1958(8)$ & $1.909(2)$ & $1.9082(19)$ & $1.942(2)$ & 92.69 \\
$\mathbf{4}$ & $2.172(2)$ & $1.895(5)$ & $1.910(3)$ & $1.937(4)$ & 94.50 \\
$\mathbf{5}$ & $2.1838(17)$ & $1.911(6)$ & $1.906(4)$ & $1.921(4)$ & 82.61 \\
\hline
\end{tabular}

${ }^{\mathrm{a}} \mathrm{X} / \mathrm{Y}: \mathrm{O} / \mathrm{N}$ atoms, ${ }^{\mathrm{b}} \mathrm{Ni}-\mathrm{N}$ (indole), ${ }^{\mathrm{c}} \mathrm{Ni}-\mathrm{N}$ (imine)

non-hydrogen atoms. All non-hydrogen atoms were refined with anisotropic displacement parameters. All hydrogen atoms were placed in ideal positions and refined as riding atoms with relative isotropic displacement parameters. The final full matrix least squares refinement converged to $R_{1}=0.0429$ and $w R_{2}=0.1159\left(F^{2}\right.$, all data). The program PLATON ${ }^{12}$ was used for checking the structure.

Some equations of interest:

$$
\begin{aligned}
R_{\text {int }} & =\Sigma\left|F_{\mathrm{o}}{ }^{2}-\left\langle F_{\mathrm{o}}{ }^{2}\right\rangle\right| / \Sigma\left|F_{\mathrm{o}}{ }^{2}\right| \\
R_{1} & =\Sigma|| F_{\mathrm{o}}|-| F_{\mathrm{c}}|| / \Sigma\left|F_{\mathrm{o}}\right| \\
w R_{2} & =\left[\Sigma\left[w\left(F_{\mathrm{o}}{ }^{2}-{F_{\mathrm{c}}}^{2}\right)^{2}\right] / \Sigma\left[w\left(F_{\mathrm{o}}{ }^{2}{ }^{2}\right]\right]^{1 / 2}\right.
\end{aligned}
$$

where

$$
\begin{aligned}
w & =q /\left[\sigma^{2}\left(F_{\mathrm{o}}{ }^{2}\right)+\left(a^{*} P\right)^{2}+b^{*} P+d+e^{*} \sin (\theta)\right] \\
\mathrm{GooF} & =S=\left[\Sigma\left[w\left(F_{\mathrm{o}}{ }^{2}-{F_{\mathrm{c}}}^{2}\right)^{2}\right] /(n-p)\right]^{1 / 2}
\end{aligned}
$$

\section{RESULTS AND DISCUSSION}

Presumed from the polymerization results of the neutral $\mathrm{Ni}(\mathrm{II})$ catalysts previously reported, ${ }^{1}$ the reactivity seems to be very sensitive to the electronic nature of the bidentate ligands as well as their bulkiness. To demonstrate those effects, we synthesized two types of $\mathrm{N}^{\wedge} \mathrm{N}$ - and $\mathrm{O}^{\wedge} \mathrm{N}$-chelating ligands and the corresponding neutral Ni complexes, $\mathbf{1}$ and $\mathbf{2}$ (Figure 1), ${ }^{13}$ and examined their ability as the catalysts for the ethylene polymerization as compared to the other catalysts, $\mathbf{3},{ }^{2 \mathrm{a}} \mathbf{4},{ }^{2 \mathrm{a}}$ and $\mathbf{5},{ }^{3}$ reported previously. The complexes were prepared by reacting trans $-(\mathrm{PPh})_{3}$ $\mathrm{NiClAr}$ (Ar: -Ph, -o-tolyl) with the Tl salts of the ligands in toluene/tetrahydrofurane and purified by recrystallizing from methylene chloride/n-pentane solution.
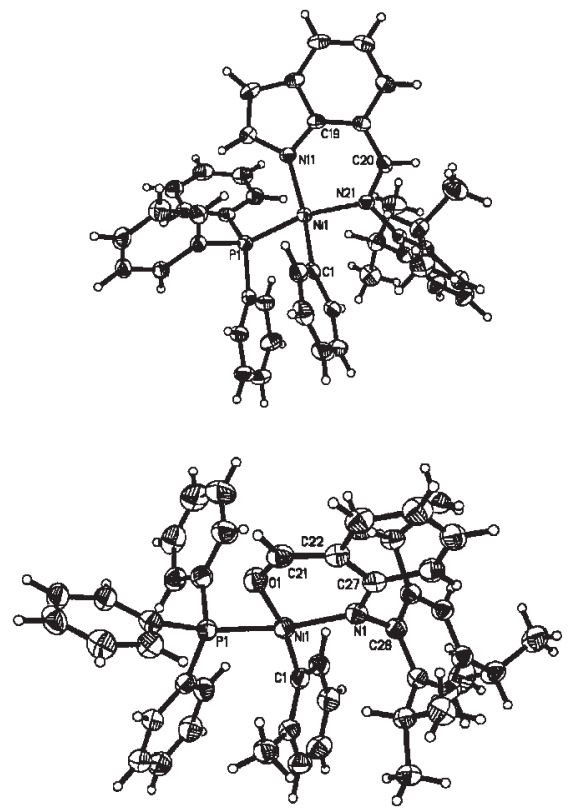

Figure 2. X-Ray Crystal Structure of 1 (top) and 2 (bottom).

The crystal structures of $\mathbf{1}$ and $\mathbf{2}$ are shown in Figure 2, respectively, and the selected bond lengths and the chelating angles are collected in Table I. ${ }^{14}$ It should be noted that the most significant difference is seen in the bond lengths between the nickel center and phosphine ligand. The $\mathrm{Ni}-\mathrm{P}$ bond length in $\mathbf{2}$ shows the longest one among the Ni complexes listed in Table I. As compared to $\mathbf{1}$ or $\mathbf{4}$, an anionic charge of the ligand of $\mathbf{2}$ seems to locate on the trans position of the triphenylphosphine ligand that is bound to the nickel center. Our current understanding is that the trans effect of the ligand brings the longest $\mathrm{Ni}-\mathrm{P}$ bond length in 2. The catalyst 5 also has long Ni-P bond length, which is one of the most active neutral nickel catalysts without using any cocatalysts. ${ }^{3}$

The results of our representative ethylene polymer- 
Table II. Results of ethylene polymerization by neutral nickel complexes ${ }^{\mathrm{a}}$

\begin{tabular}{|c|c|c|c|c|c|c|c|c|}
\hline \multirow{2}{*}{ Entry } & \multirow{2}{*}{ Cat. } & \multirow{2}{*}{$\begin{array}{l}\mathrm{Ni}(\mathrm{COD})_{2} \\
\quad \text { (eq.) }\end{array}$} & \multirow{2}{*}{$\begin{array}{c}\text { ethylene } \\
\text { (psi) }\end{array}$} & \multirow{2}{*}{$\begin{array}{c}\mathrm{MW}^{\mathrm{c}} \\
(\mathrm{g} / \mathrm{mol})\end{array}$} & \multirow{2}{*}{$\begin{array}{l}\text { Branch }^{c} \\
(/ 1000 C)\end{array}$} & \multicolumn{2}{|c|}{$\mathrm{C}=\mathrm{C}(\%)^{\mathrm{c}}$} & \multirow{2}{*}{$\begin{array}{c}\text { Activity } \\
(\mathrm{kg} / \mathrm{mol} \mathrm{h})\end{array}$} \\
\hline & & & & & & internal & terminal & \\
\hline $1^{\mathrm{b}}$ & 1 & 0 & 150 & - & - & - & - & 0 \\
\hline $1^{\prime b}$ & 1 & 2 & 150 & - & - & - & - & 0 \\
\hline 2 & 2 & 2 & 100 & 11500 & 169 & 100 & 0 & 1.3 \\
\hline 3 & 2 & 0 & 150 & 5000 & 165 & 83 & 17 & 22.6 \\
\hline 4 & 2 & 2 & 150 & 16800 & 116 & 100 & 0 & 24.0 \\
\hline 5 & 2 & 2 & 200 & 24000 & 105 & 100 & 0 & 30.8 \\
\hline
\end{tabular}

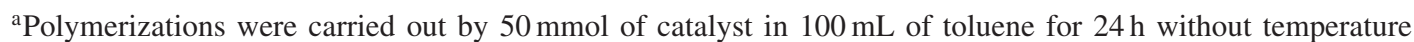
control. ${ }^{b}$ Polymerization time is $60 \mathrm{~h}$. ${ }^{\mathrm{c}}$ Determined by ${ }^{1} \mathrm{H}$ and ${ }^{13} \mathrm{CNMR}$ analysis

izations are collected in Table II. The polymerizations were conducted in toluene without any temperature control. The $\mathrm{O}^{\prime} \mathrm{N}$-chelated catalyst $\mathbf{2}$ shows moderate activity for the ethylene polymerization. Increasing the ethylene pressure from $100 \mathrm{psi}$ to $150 \mathrm{psi}$ during the polymerization resulted not only in the significant increase of productivity but also in the increase of molecular weight. Under lower pressure $(50 \mathrm{psi}, 24 \mathrm{~h})$, the polymerization activity was not observed. On the other hand, increasing the ethylene pressure to 200 psi (entry 5 in Table II), the molecular weight of polyethylene slightly increased, but the activity did not change drastically as seen in entry 2 and 3 . Moreover, $\mathbf{2}$ can show comparable polymerization activity even in the absence of $\mathrm{Ni}(\mathrm{COD})_{2}$ which is usually used as an activator. The activity does not seem to depend on the presence of $\mathrm{Ni}(\mathrm{COD})_{2}$, particularly under higher pressure, but the addition of $\mathrm{Ni}(\mathrm{COD})_{2}$ affects the molecular weight and the polymer microstructures. As mentioned in the details of the X-Ray crystal structures, the Ni-P bond should play an important role in the ethylene polymerization. Comparing 2 to 3,3 is not active for the ethylene polymerization in the absence of $\mathrm{Ni}(\mathrm{COD})_{2},{ }^{2}$ but 2 shows activity as high as the case in the presence of $\mathrm{Ni}(\mathrm{COD})_{2}$. The solid PE with higher molecular weight was obtained in entry 2 and 4 than in entry $3\left(M_{\mathrm{W}}<5000\right)$. It means that the presence of $\mathrm{Ni}(\mathrm{COD})_{2}$ has a crucial influence not on the propagation rate but on the mechanism of the chain transfer reaction such as the $\beta$-hydride elimination.

The ${ }^{1} \mathrm{H}$ and ${ }^{13} \mathrm{C}$ NMR measurements of the polyethylene obtained have revealed that the structure of the chain end as well as the branches (Table II). Interestingly, the polymerization by $\mathbf{2}$ in the absence of $\mathrm{Ni}(\mathrm{COD})_{2}$ (entry 3 ) gave highly branched polyethylene (165 branches per 1000C), whereas the polyethylene in entry 4 produced less branched structure (116/ 1000C). These results indicate that the chain transfer reaction which produces branching structures is more preferred in the absence of $\mathrm{Ni}(\mathrm{COD})_{2}$ as compared to the polymerization with $\mathrm{Ni}(\mathrm{COD})_{2}$. Interestingly, while the polyethylene obtained in entry 4 has C1-6
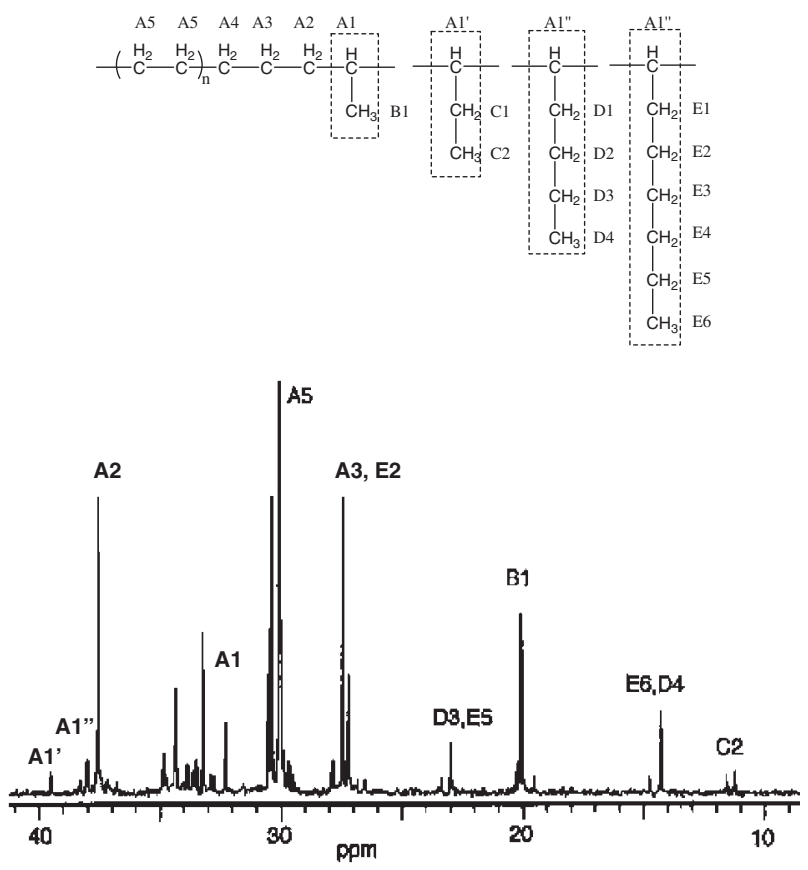

(a) without $\mathrm{Ni}(\mathrm{COD})_{2}$

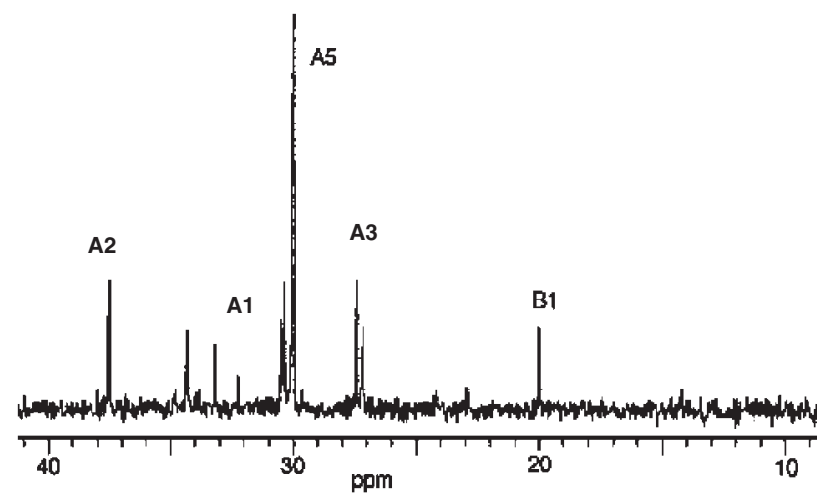

(b) with $\mathrm{Ni}(\mathrm{COD})_{2}$

Figure 3. ${ }^{13} \mathrm{C}$ NMR spectra of polyethylene obtained in entry 3 (a) and 4 (b) in Table II.

branches, one component polymerization gave predominantly methyl branches (Figure 3). The chain end structure also depends on the use of $\mathrm{Ni}(\mathrm{COD})_{2}$ as seen in Table II and Figure 4. As a result of the chain transfer reaction, the polyethylene has an unsaturated $\mathrm{C}=\mathrm{C}$ bond on the chain end. In entry $3,17 \%$ of 


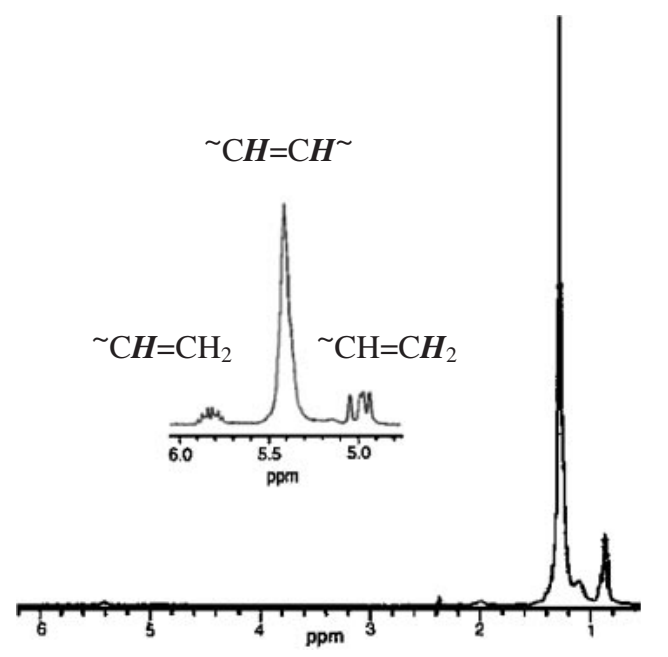

(a) without $\mathrm{Ni}(\mathrm{COD})_{2}$

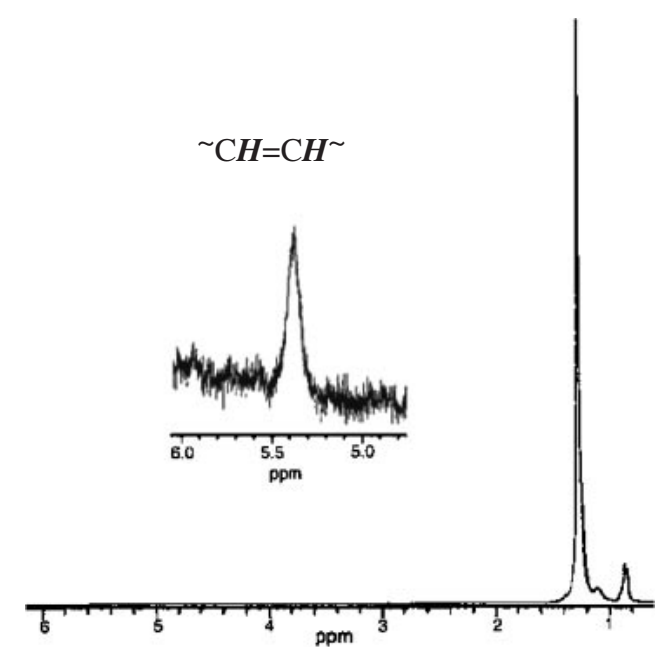

(b) with $\mathrm{Ni}(\mathrm{COD})_{2}$

Figure 4. The $300 \mathrm{MHz}{ }^{1} \mathrm{H}$ NMR spectra of polyethylene obtained in entry 3 (a) and 4 (b) in Table II.

the terminal $\mathrm{C}=\mathrm{C}$ structure was observed, but only internal $\mathrm{C}=\mathrm{C}$ structure was produced in entry 4 . This result may indicate that the polymer with terminal $\mathrm{C}=\mathrm{C}$ structure that $\pi$-coordinates to $\mathrm{Ni}$ after $\beta$-H elimination eliminates more easily because the triphenylphosphine ligand is not scavenged by $\mathrm{Ni}(\mathrm{COD})_{2}$.

The $\mathrm{N}^{\wedge} \mathrm{N}$-chelated complex $\mathbf{1}$ does not show any activity for the ethylene polymerization. From the ${ }^{1} \mathrm{HNMR}$ analysis of the reaction of $\mathbf{1}$ with ethylene, no insertion of ethylene into $\mathrm{Ni}-\mathrm{Ph}$ bond was observed at $23^{\circ} \mathrm{C}$ under $100 \mathrm{psi}$ of ethylene in benzene- $d_{6}$. It is supposed that the Ni-Ph bond could be too stabilized to initiate the polymerization due to the lower electro negativity of nitrogen atom than that of oxygen. To activate $1, \mathrm{Ni}(\mathrm{COD})_{2}$ was added to the polymerization solution of $\mathbf{1}$ but it resulted in affording precipitates of metal mirror probably due to the immediate reductive elimination. In the same reaction of 2, no $\mathrm{Ni}(0)$ precipitates appeared. Additionally, we examined $\mathrm{B}\left(\mathrm{C}_{6} \mathrm{~F}_{5}\right)_{3}$ and $\mathrm{MAO}$ as other activators, however, these Lewis acids completely inhibited the polymerization activity both of $\mathbf{1}$ and $\mathbf{2}{ }^{15}$

Acknowledgment. Dr. N. R. Brroks and Dr. V. G. Young Jr., X-Ray Crystallographic Laboratory, University of Minnesota, are thanked for the X-Ray crystal structure measurements, respectively.

\section{REFERENCES AND NOTES}

1. a) S. D. Ittel, L. K. Johnson, and M. Brookhart, Chem. Rev., 100, 1169 (2000).

b) R. Soula, J. P. Broyer, M. F. Llauro, A. Tomov, R. Spitz, J. Claverie, X. Drujon, J. Malinge, and T. Saudemont, Macromolecules, 34, 2438 (2001).

c) V. C. Gibson and S. K. Spitzmesser, Chem. Rev., 103, 283
(2003).

2. a) C. Wang, S. Friedrich, T. R. Younkin, R. T. Li, R. H. Grubbs, D. A. Bansleben, and M. W. Day, Organometallics, 17, 3149 (1998).

b) L. K. Johnson, A. M. A. Bennett, S. D. Ittel, L. Wang, A. Parthasarathy, E. Hauptman, R. D. Simpson, J. Feldman, and E. B. Coughlin, WO Patent Application 9830609 to DuPont.

c) T. R. Younkin, E. F. Conner, J. I. Henderson, S. K. Friedrich, R. H. Grubbs, and D. A. Bnasleben, Science, 287, 460 (2000).

3. F. A. Hicks and M. Brookhart, Organometallics, 20, 3217 (2001).

4. a) F. M. Bauers and S. Mecking, Macromolecules, 34, 1165 (2001).

b) R. Soula, C. Novat, A. Tomov, R. Spitz, J. Claverie, X. Drujon, J. Malinge, and T. Saudemont, Macromolecules, 34, 2022 (2001).

c) R. Soula, B. Saillard, R. Spitz, J. Claverie, M. F. Llaurro, and C. Monnet, Macromolecules, 35, 1513 (2002).

d) S. Mecking, Angew. Chem. Int. Ed., 40, 534 (2001).

e) S. Mecking, A. Held, and F. M. Bauers, Angew. Chem., Int. Ed., 41, 544 (2002).

5. G. Bartoli, G. Palmieri, M. Bosco, and R. Dalpozzo, Tetrahedron Lett., 30, 2129 (1989).

6. D. R. Dobson, J. Gilmore, and D. A. Long, SYNLETT, 79 (1992).

7. R. A. Betlett, H. V. R. Dias, and P. P. Power, J. Organomet. Chem., 341, 1 (1988).

8. J. S. Baum, M. Condon, and D. A. Shook, J. Org. Chem., 52, 2983 (1987).

9. M. Hidai, T. Kashiwagi, T. Ikeuchi, and Y. Uchida, J. Organomet. Chem., 30, 279 (1971).

10. A. Altomare, G. Cascarno, C. Giacovazzo, and A. Gualardi, J. Appl. Crystallogr., 26, 343 (1993).

11. Bruker Analytical X-Ray Systems, Madison, WI (1998).

12. A. L. Spek, Acta Crystallogr., Sect. A, 46, C34 (1990). PLATON, A Multipurpose Crystallographic Tool, Utrecht Uni- 
versity, Utrecht, The Netherlands, A. L. Spek (2000).

13. B. M. Novak, G. Tian, M. Nodono, and P. Boyle, PMSEPrepr., 223rd ACS Natl. Meet., Orland, FL, April 7-11, 2002; Am. Chem. Soc., Washington D.C., 2002, Vol. 86. p. 326.

14. Crystal data for $\mathbf{1}: \mathrm{C}_{45} \mathrm{H}_{43} \mathrm{~N}_{2} \mathrm{NiP}, \mathrm{M}=701.49$, monoclinic, temperature $=173(2) \mathrm{K}$, crystal size $0.40 \times 0.40 \times 0.22$ $\mathrm{mm}^{3}, \quad a=16.832(3), \quad b=11.7136(18), \quad c=19.943(3) \AA$, $V=3672.8(10) \AA^{3}, \quad T=173(2) \mathrm{K}$, space group $P 2_{1} / c$, $Z=4, \mu(\mathrm{Mo}-\mathrm{K} \alpha)=0.606 \mathrm{~mm}^{-1}, 26281$ reflections collected, indipendent reflections $=6511\left(R_{\text {int }}=0.065\right)$, final $w R_{2}=0.0812$. Crystal data for 2: $\mathrm{C}_{47} \mathrm{H}_{50} \mathrm{NNiOP}, \mathrm{M}=$ 734.56 , orthorhombic, temperature $=173(2) \mathrm{K}$, crystal size $0.38 \times 0.23 \times 0.10 \mathrm{~mm}^{3}, a=11.3284(12), b=18.380(2)$, $c=18.663(2) \AA, \quad V=3885.9(7) \AA^{3}, T=173(2) \mathrm{K}$, space group $P 2{ }_{1} 2{ }_{1}{ }_{1}, Z=4, \mu(\mathrm{Mo}-\mathrm{K} \alpha)=0.577 \mathrm{~mm}^{-1}, 34364$ reflections collected, indipendent reflections $=8866\left(R_{\text {int }}=\right.$ 0.0311 ), final $w R_{2}=0.1093$.

15. The polymerization by 2 with $\mathrm{B}\left(\mathrm{C}_{6} \mathrm{~F}_{5}\right)_{3}$ (2eq.) or MAO (2eq.) was conducted under the same condition of entry 4 in Table II. 